\begin{tabular}{|c|c|c|}
\hline 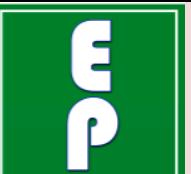 & $\begin{array}{c}\text { International Journal of Current Research } \\
\text { and Academic Review }\end{array}$ & 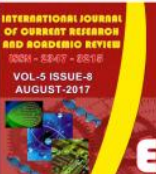 \\
\hline $\begin{array}{l}\text { EXCELLENT } \\
\text { PUBLISHERS }\end{array}$ & $\begin{array}{c}\text { ISSN: 2347-3215 (Online) ;,; Volume 5 ,; Number 8 (August-2017) } \\
\text { Journal homepage: http://www.jicrar.com }\end{array}$ & \\
\hline
\end{tabular}

doi: https://doi.org/10.20546/ijcrar.2017.508.015

\title{
Impact of Information Technology Strategy on Decision Making in Healthcare Sector: An empirical study in Baghdad Teaching hospital
}

\author{
Safaa Tayyeh Mohammed* \\ College of Administration and Economy, University of Kufa, Al-Najaf Al-Ashraf/ Republic of Iraq \\ *Corresponding author
}

\begin{abstract}
This study aims to identify the relationship between information technology strategy and decision making in health care sector in particular Baghdad teaching hospital in Iraq, to achieve the aims a model has been suggested, it tested by structural equation modeling (SEM). To investigate the relationship between the variables, it has been used the linear regression statistics computing the linear correlation coefficient and regression between variables. The research pointed there is high positive relationship between information technology strategy and decision making. Empirical findings are analyzed and suggestions for improving information technology strategy of healthcare.
\end{abstract}

\author{
Article Info \\ Accepted: 30 July 2017 \\ Available Online: 20 August 2017

\section{Keywords} \\ Information Technology Strategy, \\ Strategic Planning, \\ Knowledge Workers, \\ Information System, \\ Decision Making
}

\section{Introduction}

Nowadays technology is becoming an important and critical factor for organizational competitiveness, the way that it is used within organization is essential not only for success, but also among those who use it, (Balatesh, 2015) given the changing business environment today, organizations face the challenges of global competitiveness. Moreover, organizations face more and more issues such as rapid technological changes, product life cycle, and high market volatility. To meet these challenges, organizations should be able to effectively manage resources(Zoltan \& Lajos, 2012) that's will be achieved with the adoption of Information technology strategy(Hung et al., 2012).

Despite there are many studies about the term "technology strategy ", less attention has been paid to the role and use it to improve decision making in medical field and there is a lack of related empirical research. So, this paper attempted to answer the following research question:how medical decisions can become more rational at supporting information technology strategy, Additionally, doctors in hospital have to consider risk management, where poor information and tools can result in errors in medical decisions. therefore, medical institutions have to have a rational decisions, that's may achieve with suitable technology strategy, and that what we try to discuss here in this paper. Accordingly, this research attempts to investigate the impact of information technology strategy to improve decision making.

\section{Literature review}

Professionals in business and systems are increasingly deals with suggestions for using strategic information technology strategically (Kemerer \& Sosa, 1991). In 
order to understand the relationship between (information technology strategy and decision making), we executed a detail analysis to the paths between the (sub- dimensions) that related to the main variables (strategic planning, knowledge workers, information system).The information technology strategy focuses on the environmental analysis of information technology and the choice of what are suitable for the needs of consumers and users (Chiesa, 2001). These helps organizations to have a long-term competitive advantage (Hamel \& Parahald 1990) (Khalil \& Tm 2000). Because the user and the consumer are always looking for rapid changes in electronic products (Chiesa, 2001), thus, organizations should use advanced and sophisticated information technology to meet growing needs (Schilling \& Hill, 1998) point out that the purpose of the technology is to identify and develop tools that will resolve long-term competition processes in the organization that enhance user confidence in this technology. Information technology strategy can be defined as identifying information architecture, acquiring IT hardware and software to implement it, and ensuring continuity of service (George \& O'Brien, 2013). A combination of explicit and implicit plans and guides for supply demand of information in organization and these compatible with external and internal environment in order to realize the vision and objective (Wilson,2013).

\section{Relation between information technology strategy andorganization strategy}

Organization managers and Information Technology managers continue to view information technology as an integrated, dynamic, and efficient process in all parts of the organization, Thus focusing on initiatives that improve the relationship between information technology and the Organization (Luftman et al., 2013). The ideal situation is that business strategy and information technology strategy complement and support each other in the business environment, As new information technology evolves collaboratively with new organizational strategies and new structures behaviors as illustrated in Figure (1) (McKeen\& Smith, 2009).

So the Information technology strategy is derived from the organization's strategy and business requirements, taking into account external and internal conditions such as legal conditions and availability of resources (Aref,2010 :44). The main components of the building steps of the Information technology strategy are depending on the (house) strategy that described in (Figure 2) as follow:
- The roof of the house represents the location and strategic objectives.

- The horizontal pillars of the home are the main assets of information technology.

- The vertical pillars of the house: represent aspects related to the strategy.

\section{The dimensions of Information technology strategy}

Researchers provide many dimensions of information technology as it illustrated in (Table 1), and this research will depend on the common dimensions from this survey which will be (strategic planning,knowledge workers, information system)

\section{Strategic Planning}

Strategic planning determines where the organization goes over a year or more and how it gets there, and the process is either organization-wide or focused on a key function (McNamara, 2008) it is an organizational activity that used to set the priorities focusing resources and energy,ensure that organization member are working toward common goals, and adjust the direction in response to a changing environment (Akdeniz, 2015) it means the strategic planning as aroadmap for change, future priorities and guiding the decision-making process and selecting appropriate linkages (Nadler, 2012) and it represent the outcome of strategic thinking, where the goals are set to clarify the direction should taken by the organization, and guided by strategic planning in determining where to put resources and help in the development and identification of the objectives of the organization (Gilligan \& Wilson, 2003) to achievethese objective and demonstrate organization status by making priority with resources according to the objectives as an attempt to guide its development over the time (Kriemads \& Theakou,2007) as it is a rational process from top to bottom through which we can manage future success programs (Rothaermel, 2013).

So we can say that strategic planning is an administrative tool and roadmap focus on priorities and use to support the decisions of leaders by increasing their awareness of goals and specific purpose, which is to help the organization to perform better work.

\section{Knowledge Workers}

knowledge workers are the new groups formed in the age of knowledge economy, Many scholars, have described 
the knowledge workers as people who understand and use symbols, concepts, knowledge and information, Arthur Anderson describes them as groups that possess thought, (Liu \& Chai, 2011) who have intellectual means to produce (Noe et al.,2006) Francis of the famous Canadian world points out that knowledge workers are the people who create wealth with the brain rather than the hands, adding value to the products of the organization through their creations, analysis, judgment, integration and design ,At present, the generally accepted definition of knowledge workers as intellectual workers who possess strong knowledge and creativity and can use learning new technology to improve work (Bildstein,etal.,2013 :790)and Knowledge workers add value to the work because of what they know (Denisis\& Griffin,2001 :504) and what they have of high degrees of experience, education and experience and the basic purpose of their work involves the creation, distribution and application of knowledge (Davenport, 2005) consequently, Drukerillustrates knowledge workers by the following characteristics: (Siez, 2011).

- Is a person who has important knowledge of the organization and is often the only person who owns it.

- Is the person who can use knowledge in his work.

- Knowledge is relatively intangible, A worker may not know it first, It understands its importance, Other workers in the organization have a limited view of knowledge. They cannot learn or can not use it.

- The person who works most intellectually

\section{Information System}

Information system is represents the process of collecting data from the components of the information system or the external environment, storing information used in the system, processing information, disseminating information to the external environment and feedback(Reix,2000 :20) and it includes set of procedures and methods that include data collection, analysis, for decision-making (shalan,2015:33) In order to the information system to be suitable, it should be characterized by the following (shalan,2015:33)

- Provide timely and accurate information.

- Achieving the objectives of the organization.

- Improved use of FAO resources.

- Improved communication within the organization and the environment.

- Supporting decision-making within the organization.

- Ensure confidentiality of information.
- Ease of application and use without the need for great experience and training.

So, the Strategic Information Systems become an imperative action to help the organization in order to recognize the vital application and adjesting organizations technique to achieve goals (Altamem, et al., 2014)

\section{Decision making}

The decision-making is one of the main functions of the management of organization, the administration faces many problems related to decision making, It tries to find the appropriate solutions after studied, analyzed and evaluated.(Balatesh,2015:22) The decision-making process can be considered as one of the difficult and complicated administrative tasks that administration should exercise.(moori\& lauden,2012 :44) The use of information system to make various administrative decisions, and the management of the organization must be able to distinguish and determine the tools thatappropriate to make decisions (Siez,2011).

Decision making can be defined as the process of adaptation using of means to reach the goals, and as the core of the work in an organizations (Brown \& Dennis,2000) and choose from alternatives, by the process is adopted, and chosen the most obvious alternative (Shimary \& Azzawi,2013) and decision making is very important and sensitive so it need many tools to make.

\section{Empirical study}

\section{Sampling}

The research used a descriptive survey research design to collect data from a sample of 156 staff (doctors)of Baghdad teaching Hospital who were selected to participate in this study. Baghdad Teaching Hospital is one of most important hospitals in Iraq, it belong to Baghdad medicine city, its offer services in several type of service (surgery, Gynecology \& Obstetric, Kidney, $\mathrm{CCU}, \mathrm{RCU}, .$. etc) and it is responsible for training to the students of college of medicine, it has (200) doctors and (302) postgraduates doctors (the official site of ministry of health).

In this research a simple random sampling methods used to pick the respondents according to (Steven equation for sampling). 


\section{Research Measurements}

Table (2) shows the Research Measurements.

\section{Response Rate}

The research used a descriptive survey research design to collect data from a sample of 156 staff (doctors) of Baghdad teaching medical city who were selected to participate in this study. it distributed (200) questionnaire

It employed simple random sampling methods to pick the respondents according to (Steven equation for sampling) it should be (138)from total population of (216),so the collected are (156) it be $78 \%$ of response rate, 147 questionnaires which appropriate to analysis and 9 are outlier or not fully properly. As table (3) shown.

\section{Respondent's characteristics}

The table (4) show the Respondents characteristics that refer to the majority of sample is male (65.3\%), the age refer to $(34.7 \%)$ less than 30 years, $(26.5 \%)$ between (30$40)$ and $(20.4 \%)$ between (41-50) and the other (18.4\%) are more than 50 years, and about the education it been the majority of respondents are BSC (51.7\%), the (36\%) PHD and (12.3\%) MSC.

\section{Normality Test}

Table (5) show the normality test for the data of the study, it depend on skewness and kurtosis statistics,and the accepted value should be between $(+1.96,-1.96)$ and the results show that the data follow the normal distribution.

\section{Confirmatory factor analysis (CFA) test}

In order to test the data that valid to the factors, structural equation modeling has been used to test CFA, it should be at the level of acceptable threshold that shown in table (6)

The figure (3) and (4) shown the accept modification model to be fit with the fit indices conditions and CFA. If not all data accept it will use modification indices to correct them. The condition to fit index are statistically achieved due to (GFI $>0.90$, AGFI $>0.90$, CFI $>0.95$, $\mathrm{NFI}>0.95$, RMSEA $<0.08)$.

Table.1 Dimensions of Information technology strategy

\begin{tabular}{|c|c|c|c|c|c|c|c|c|c|c|c|c|c|c|c|}
\hline Dimensions & 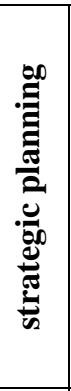 & 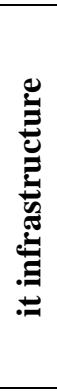 & 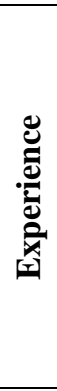 & 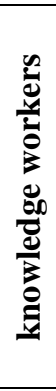 & 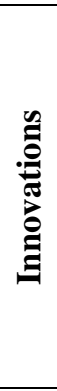 & 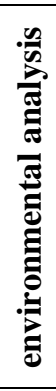 & 苞 & 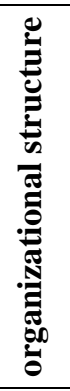 & 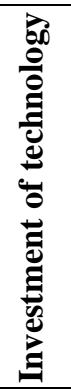 & 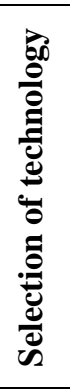 & 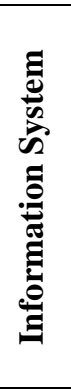 & 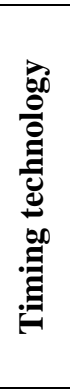 & 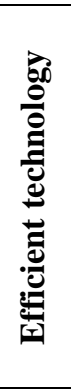 & 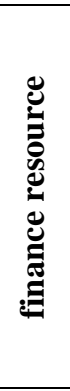 & 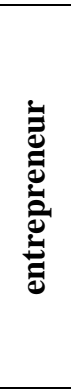 \\
\hline Chiesa,2001 & & & & & $*$ & & & & & & & $*$ & $*$ & & \\
\hline David,2002 & & & & $*$ & & $*$ & & & & & & & & & \\
\hline Spinks, 2005 & $*$ & & & & & $*$ & & & & & & & & & \\
\hline Hadrawi2010 & $*$ & & $*$ & & $*$ & & $*$ & & & & $*$ & & $*$ & & $*$ \\
\hline Dahan,2011 & $*$ & & & & & & & & $*$ & $*$ & $*$ & $*$ & & & \\
\hline $\begin{array}{l}\text { O'Brien \& } \\
\text { Marakas,2011 }\end{array}$ & * & * & & $*$ & & & & $*$ & & & * & & & & \\
\hline Siez,2011 & & & & & & & & & & & & & & & \\
\hline Hindi,2012 & & * & & $*$ & & & & & & & & & $*$ & $*$ & \\
\hline Wilson,2013 & $*$ & $*$ & & $*$ & & & & $*$ & & & & & & & \\
\hline Balatesh,2015 & $*$ & & & & & & & & & & $*$ & & & & \\
\hline Shalan,2015 & & & & & & & & & & & $*$ & & & & \\
\hline Daft,2016 & & & & & & & & & & $*$ & $*$ & & & $*$ & \\
\hline
\end{tabular}


Table.2 Research Measurements and coding

\begin{tabular}{|c|c|c|c|}
\hline Variables & dimensions & items & Measurement \\
\hline \multirow{3}{*}{ Information } & & 15 & O’Brien \& Marakas,2011 \\
\cline { 2 - 4 } Technology Strategy & Strategic Planning & 5 & McNamara, 2008 \\
& & & Akdeniz,2015 \\
\cline { 2 - 4 } & Knowledge Workers & 5 & Bildstein,etal.,2013 \\
\cline { 2 - 4 } & Information System & 5 & shalan,2015 \\
\hline Decision Making & & 6 & Balatesh,2015 \\
\hline
\end{tabular}

Table.3 The response rate of sample

\begin{tabular}{|l|c|c|}
\hline & No. & \\
\hline Distributed & $\mathbf{2 0 0}$ & $\mathbf{1 0 0 . \%}$ \\
\hline Collected & 156 & $78 \%$ \\
\hline Outlier & 9 & $5.7 \%$ \\
\hline Ready & 147 & $73.5 \%$ \\
\hline
\end{tabular}

Table.4 Respondent's characteristics

\begin{tabular}{|l|l|c|c|}
\hline \multicolumn{2}{|l|}{ Characteristic } & No. & \% \\
\hline \multirow{4}{*}{ Gender } & Male & 96 & 65.3 \\
\cline { 2 - 4 } & Female & 51 & 34.7 \\
\cline { 2 - 4 } & Total & 147 & 100.0 \\
\hline \multirow{4}{*}{ Age } & less than 30 & 51 & 34.7 \\
\cline { 2 - 4 } & $30-40$ & 39 & 26.5 \\
\cline { 2 - 4 } & $41-50$ & 30 & 20.4 \\
\cline { 2 - 4 } & More than 50 & 27 & 18.4 \\
\cline { 2 - 4 } & Total & 147 & 100.0 \\
\hline Education & BSC & 76 & 51.7 \\
\cline { 2 - 4 } & MSC & 18 & 12.3 \\
\cline { 2 - 4 } & PHD & 53 & 36.0 \\
\cline { 2 - 4 } & Total & 147 & 100.0 \\
\hline
\end{tabular}


Table.5 Normality test for the data

\begin{tabular}{|c|c|c|c|c|c|c|c|}
\hline & Variable & $\min$ & $\max$ & skew & c.r. & kurtosis & c.r. \\
\hline \multirow{16}{*}{ 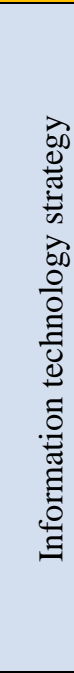 } & q15 & 1.000 & 5.000 & -1.032 & -5.107 & 1.196 & 2.959 \\
\hline & q14 & 1.000 & 5.000 & -1.087 & -5.382 & 1.170 & 2.895 \\
\hline & q13 & 1.000 & 5.000 & -.451 & -2.234 & -.354 & -.876 \\
\hline & $\mathrm{q} 12$ & 1.000 & 5.000 & -1.031 & -5.101 & .606 & 1.499 \\
\hline & q11 & 1.000 & 5.000 & -1.154 & -5.710 & 1.274 & 3.154 \\
\hline & $\mathrm{q} 10$ & 1.000 & 5.000 & -.528 & -2.613 & -.227 & -.561 \\
\hline & q9 & 1.000 & 5.000 & -.271 & -1.340 & -.794 & -1.966 \\
\hline & q8 & 1.000 & 5.000 & -.990 & -4.901 & .642 & 1.588 \\
\hline & q7 & 1.000 & 5.000 & -.959 & -4.745 & 1.593 & 3.943 \\
\hline & q6 & 1.000 & 5.000 & -.679 & -3.360 & .014 & .036 \\
\hline & $q 5$ & 1.000 & 5.000 & .512 & 2.536 & -.769 & -1.903 \\
\hline & $\mathrm{q} 4$ & 1.000 & 5.000 & -.503 & -2.491 & -.689 & -1.705 \\
\hline & q3 & 1.000 & 5.000 & .268 & 1.329 & -.938 & -2.323 \\
\hline & $q 2$ & 1.000 & 5.000 & .086 & .424 & -1.087 & -2.691 \\
\hline & $\mathrm{q} 1$ & 1.000 & 5.000 & -.335 & -1.659 & -1.062 & -2.629 \\
\hline & Multivariate & & & & & 29.183 & 7.834 \\
\hline \multirow{8}{*}{ 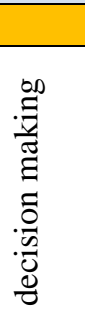 } & Variable & $\min$ & $\max$ & skew & c.r. & kurtosis & c.r. \\
\hline & y6 & 1.000 & 5.000 & -.410 & -2.029 & -.373 & -.923 \\
\hline & y5 & 1.000 & 5.000 & -.171 & -.845 & -.861 & -2.130 \\
\hline & $\mathrm{y} 4$ & 1.000 & 5.000 & -1.045 & -5.170 & 1.209 & 2.993 \\
\hline & $\mathrm{y} 3$ & 1.000 & 5.000 & -.744 & -3.685 & .014 & .035 \\
\hline & $\mathrm{y} 2$ & 1.000 & 5.000 & -1.348 & -6.672 & 2.880 & 7.127 \\
\hline & y1 & 1.000 & 5.000 & -1.043 & -5.163 & .729 & 1.803 \\
\hline & Multivariate & & & & & 11.679 & 7.226 \\
\hline
\end{tabular}

Table.6 Fit indices conditions

\begin{tabular}{|c|c|c|}
\hline Fit Index & $\begin{array}{rr}\text { Acceptable } & \begin{array}{r}\text { Threshold } \\
\text { Levels }\end{array}\end{array}$ & Description \\
\hline $\begin{array}{l}\text { Absolute Fit } \\
\text { Indices Chi- } \\
\text { Square X2 }\end{array}$ & $\begin{array}{l}\text { Low } \chi^{2} \text { relative to } \\
\text { degrees of freedom with } \\
\text { an insignificant } p \text { value } \\
(p>0.05)\end{array}$ & \\
\hline $\begin{array}{c}\text { Relative } \chi^{2} \\
\left(\chi^{2} / \mathrm{df}\right)\end{array}$ & $\begin{array}{l}\text { 2:1 (Tabachnik and } \\
\text { Fidell, 2007) } \\
\text { 3:1 (Kline, 2005) }\end{array}$ & Adjusts for sample size. \\
\hline (RMSEA) & $\begin{array}{l}\text { Values less than } \mathbf{0 . 0 7} \\
\text { (Steiger, 2007) }\end{array}$ & $\begin{array}{c}\text { Has a known distribution. Favors parsimony. Values } \\
\text { less than } 0.03 \text { represent excellent fit. }\end{array}$ \\
\hline GFI & Values greater than 0.95 & $\begin{array}{c}\text { Scaled between } 0 \text { and 1, with higher values indicating } \\
\text { better model fit. This statistic should be used with } \\
\text { caution. }\end{array}$ \\
\hline AGFI & Values greater than 0.95 & $\begin{array}{l}\text { Adjusts the GFI based on the number of parameters in } \\
\text { the model. Values can fall outside the } 0-1.0 \text { range. }\end{array}$ \\
\hline RMR & $\begin{array}{l}\text { Good models have small } \\
\text { RMR (Tabachnik and } \\
\text { Fidell, 2007) }\end{array}$ & $\begin{array}{c}\text { Residual based. The average squared differences } \\
\text { between the residuals of the sample covariance and } \\
\text { the residuals of the estimated covariance. }\end{array}$ \\
\hline SRMR & $\begin{array}{l}\text { SRMR less } 0.08 \text { (Hu\& } \\
\text { Bentler, 1999) }\end{array}$ & $\begin{array}{l}\text { Standardized version of the RMR. Easier to interpret } \\
\text { due to its standardized nature. }\end{array}$ \\
\hline \multicolumn{3}{|c|}{ Incremental Fit Indices } \\
\hline NFI & Values greater than 0.95 & $\begin{array}{l}\text { Assesses fit relative to a baseline model which } \\
\text { assumes no covariance between the observed } \\
\text { variables. Has a tendency to fit in small samples. }\end{array}$ \\
\hline NNFI (TLI) & Values greater than 0.95 & $\begin{array}{l}\text { Non-normed, values can fall outside the } 0-1 \text { range. } \\
\text { Favours parsimony. } \\
\text { Performs well in simulation studies (Sharma et al, } \\
\text { 2005; McDonald and Marsh, 1990) }\end{array}$ \\
\hline CFI & Values greater 0.95 & Normed. 0-1 range. \\
\hline
\end{tabular}

Source: Daire H., Joseph C., Michael R. Mullen, Structureal Equation Modelling: Guidelines Determining Model Fit, Journal Of Business Research Methods Volume 6 Issue 1,2008:58. 
Table.7 Regression results

\begin{tabular}{|cccccccc|}
\hline $\begin{array}{c}\text { Strategic } \\
\text { Planning }\end{array}$ & 1.634 & 0.588 & $0.730^{* *}$ & 0.532 & 0.529 & 164.975 & 0.000 \\
\hline $\begin{array}{c}\text { Knowledge } \\
\text { Workers }\end{array}$ & 1.427 & 0.597 & $0.693^{* *}$ & 0.481 & 0.477 & 134.346 & 0.000 \\
\hline $\begin{array}{c}\text { Information } \\
\text { System }\end{array}$ & 1.149 & 0.675 & $0.736^{* *}$ & 0.542 & 0.539 & 171.717 & 0.000 \\
\hline IS Strategy & 0.672 & 0.867 & $0.675^{* *}$ & 0.455 & 0.452 & 121.222 & 0.000 \\
\hline \multicolumn{7}{c}{$\mathbf{f}$ table $(\mathbf{0 . 0 5})=\mathbf{3 . 9 2} \mathbf{f}$ table $\mathbf{( 0 . 0 1 )}=\mathbf{6 . 8 5}$} \\
\hline
\end{tabular}

$*$ Sig on $a<=0.05 * * \operatorname{sig}$ on $a<=0.01$

Table.8 Multi regression results

\begin{tabular}{|c|c|c|c|c|c|c|c|}
\hline & $a$ & $\bar{B}$ & $\bar{r}$ & $\overline{\mathbf{R}^{2}}$ & Adj- $R^{2}$ & $\bar{F}$ & Sig \\
\hline $\begin{array}{l}\text { Strategic } \\
\text { Planning }\end{array}$ & \multirow{3}{*}{0.740} & 0.263 & \multirow{3}{*}{$0.814 * *$} & \multirow{3}{*}{0.663} & \multirow{3}{*}{0.656} & \multirow{3}{*}{93.772} & 0.000 \\
\hline $\begin{array}{l}\text { Knowledge } \\
\text { Workers }\end{array}$ & & 0.227 & & & & & 0.000 \\
\hline $\begin{array}{c}\text { Information } \\
\text { System }\end{array}$ & & 0.301 & & & & & 0.000 \\
\hline & & f table & $=3.92$ & ole $(0$. & $=6.85$ & & \\
\hline
\end{tabular}

Fig.1 Relation between new technology, behavior, strategy

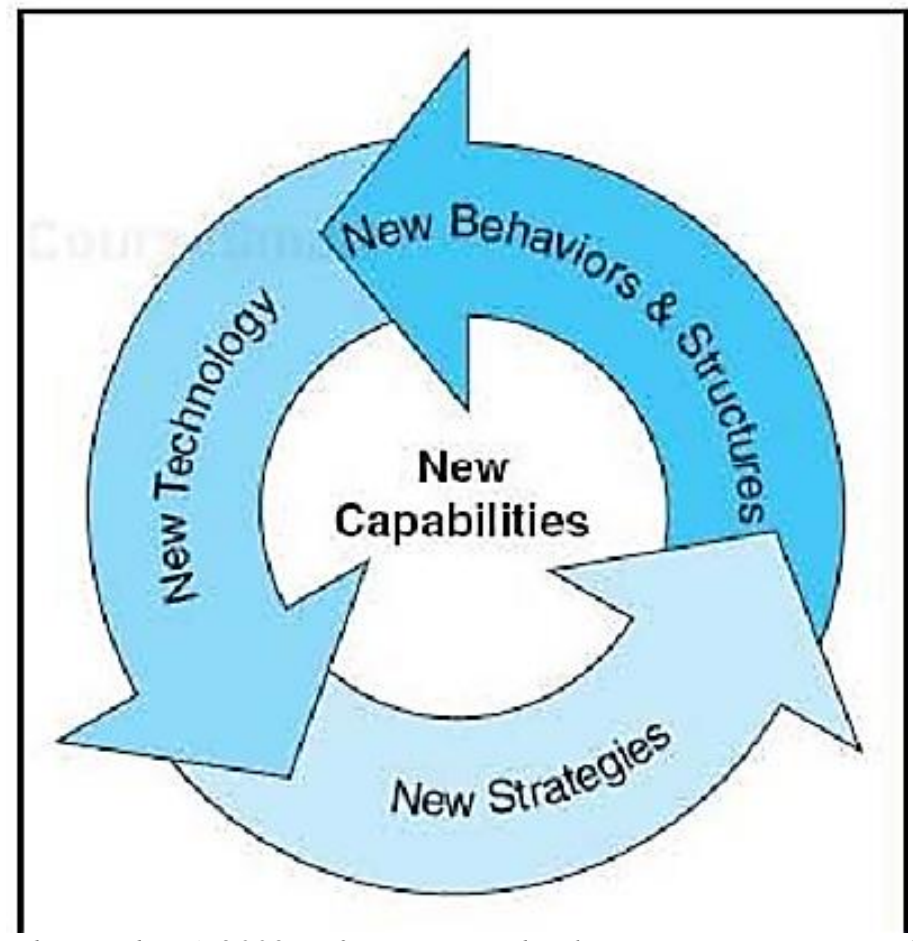

Source: McKeen, James D \& Smith, Heathcr A,2009, Information technology strategy In action, 1st ed, Pearson Education, Inc., Upper Saddle River, New Jersey,p:15. 
Fig.2 Information Technology Strategy House

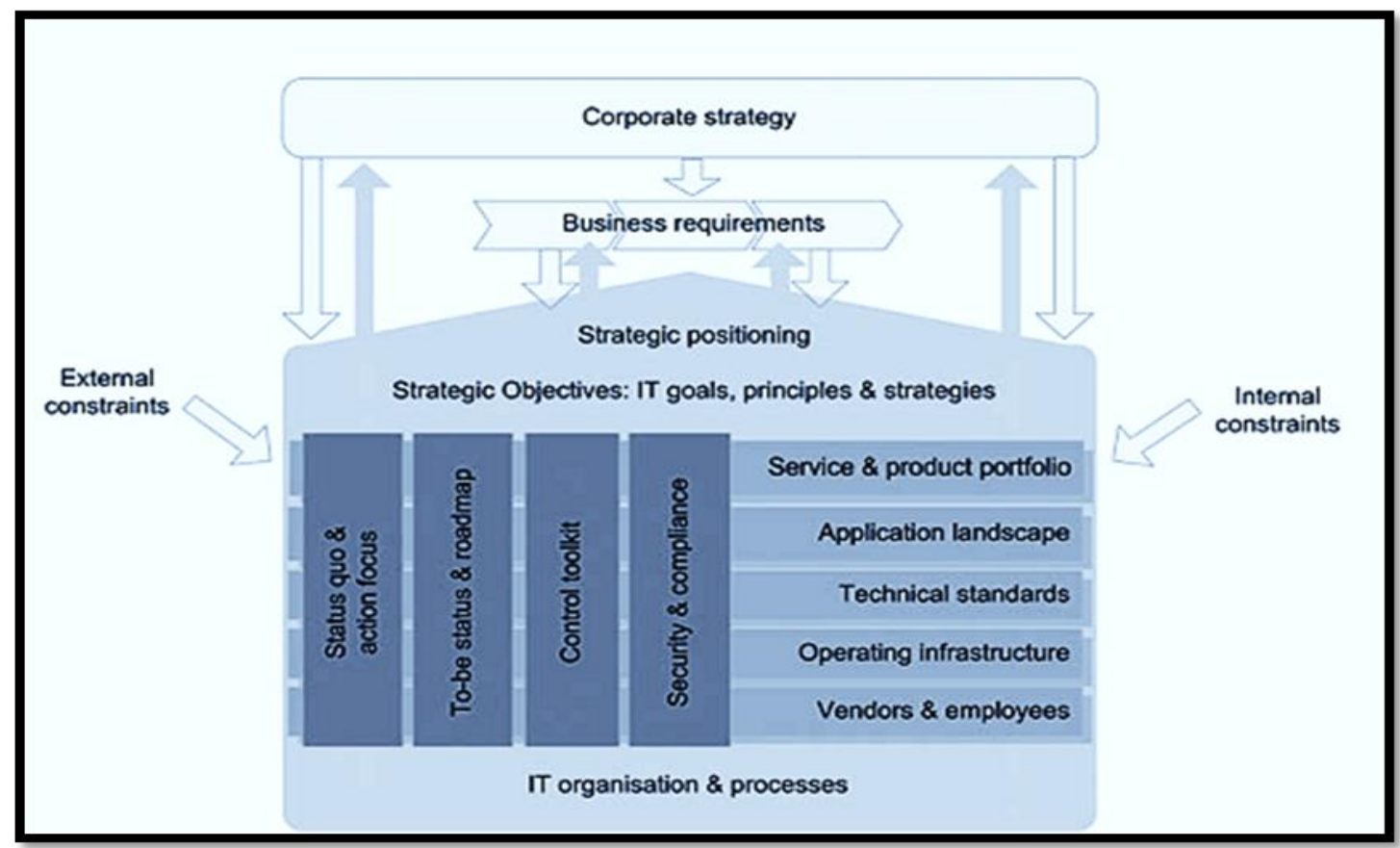

Source : Hanschke, Inge, (2010), Strategic IT Management, A Toolkit for Enterprise, Architecture Management, Springer-Verlag Berlin Heidelberg, 2010,p:44.

Fig.3 Modified Model For Information technology strategy

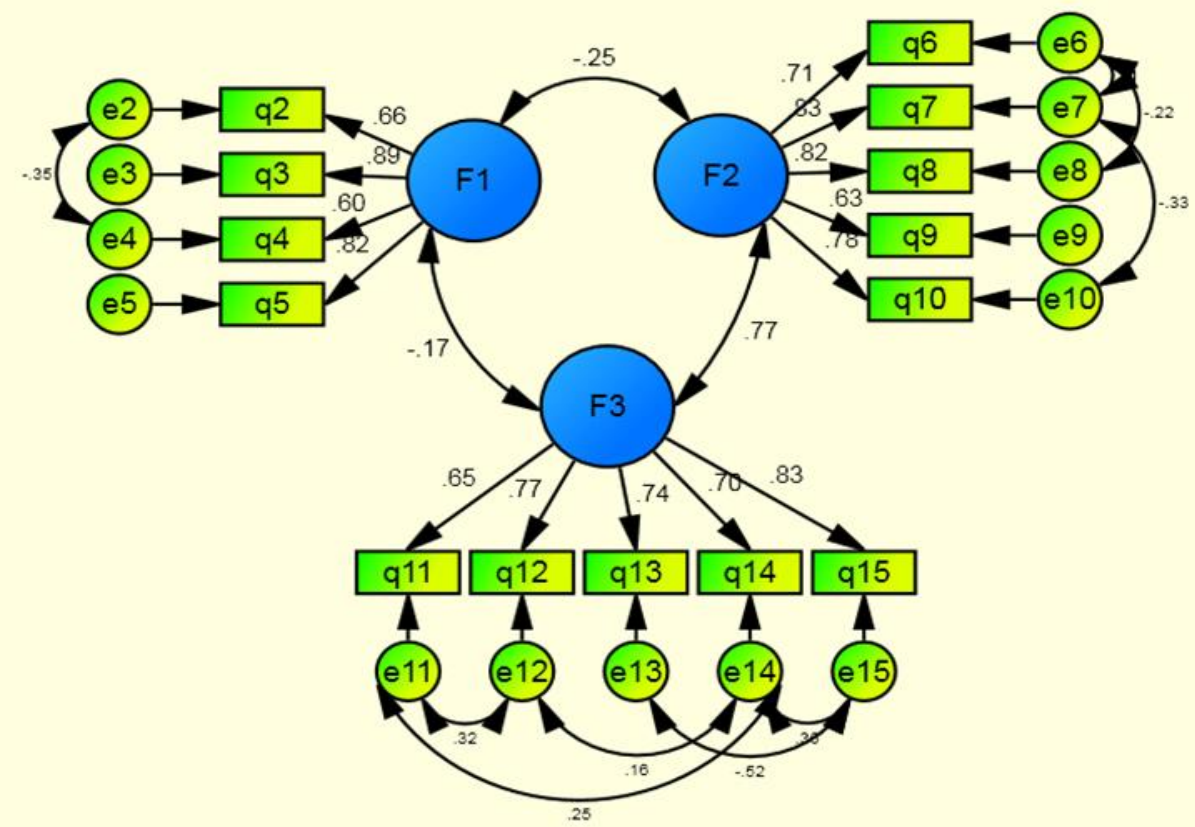

Model Summary

Chi-square.......84.355 RATIO.......1.298 DF........65

RMSEA......0.045 GFI=0.919 AGFI=0.901 CFI=0.981 


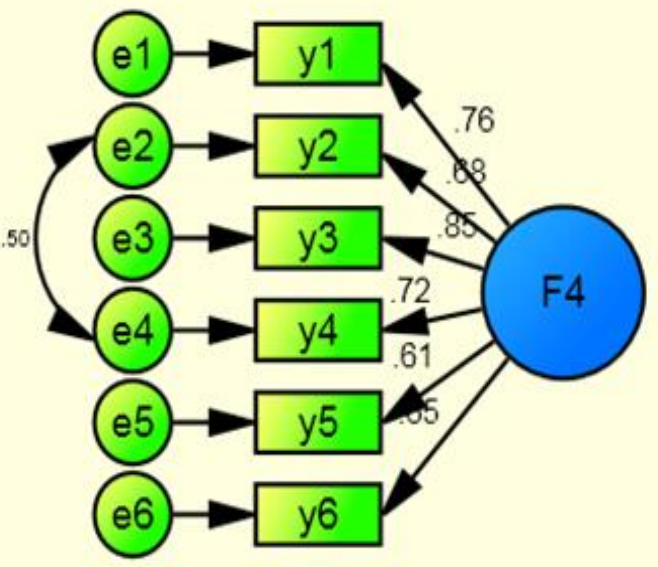

Model Summary

Chi-square.......13.647 RATIO......1.706 DF.........8

RMSEA......0.070 GFI $=0.971 \quad A G F I=0.901 \quad C F I=0.986$

Fig.5 Research Conceptual Model

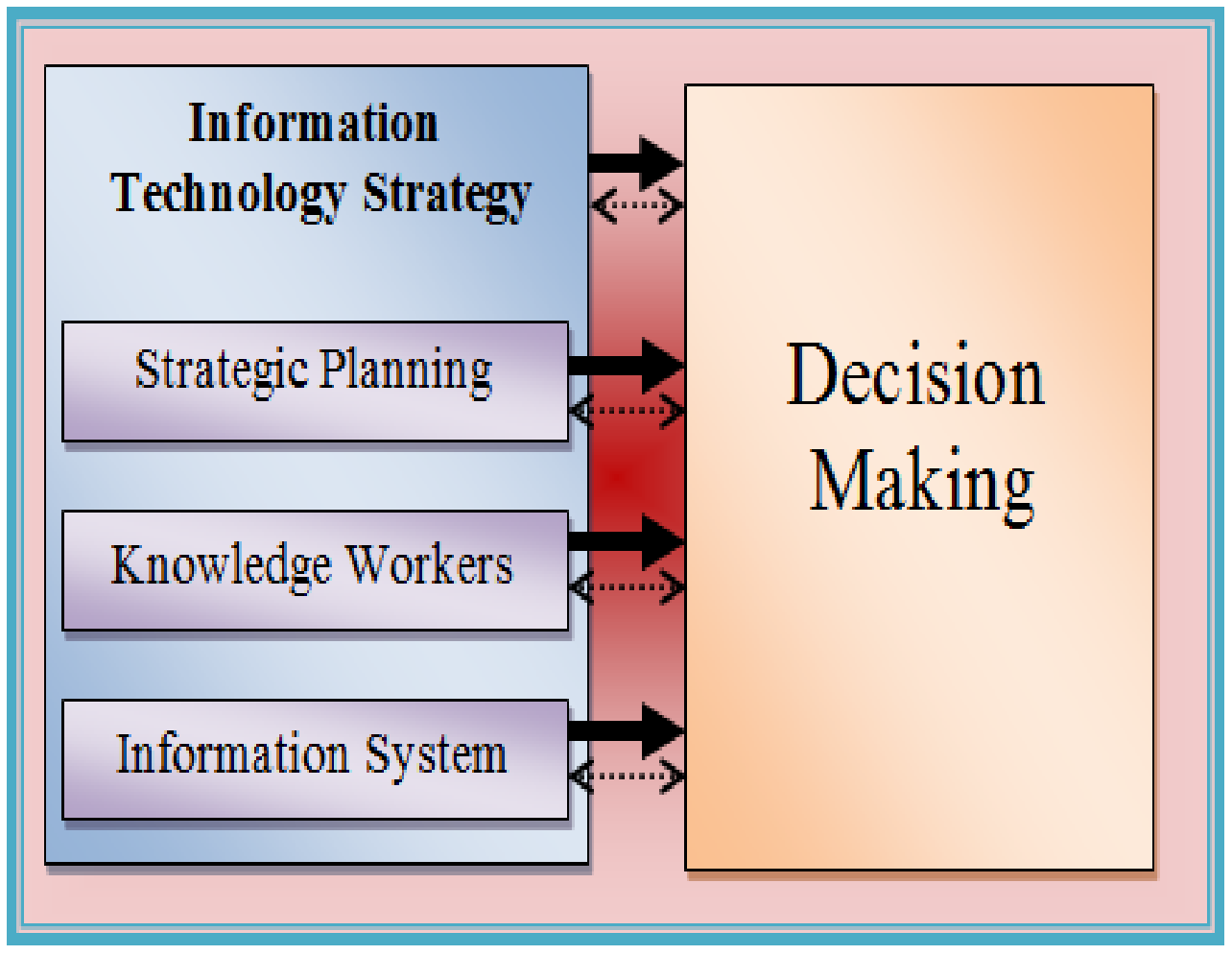


Fig.6 Multi regression results

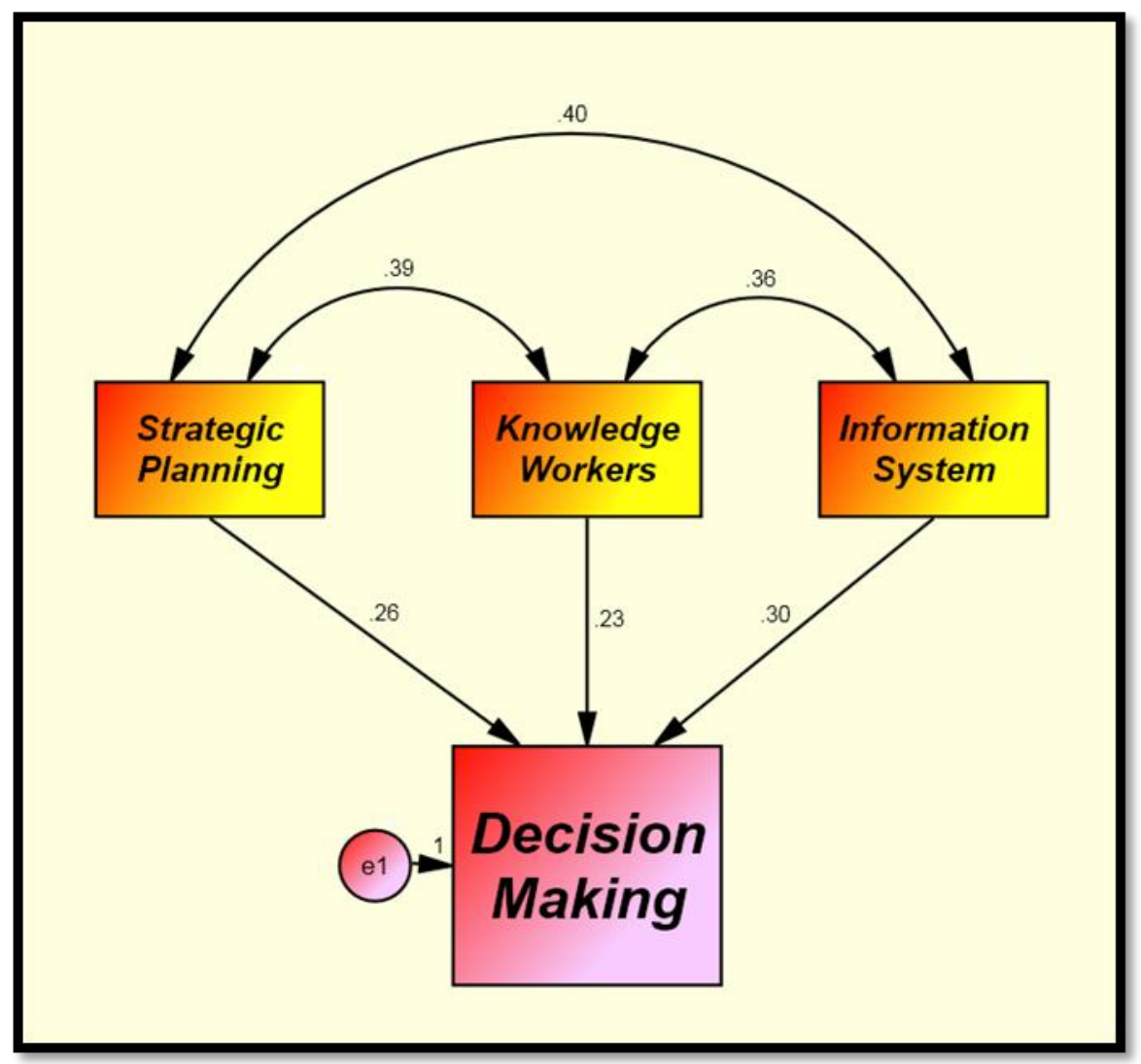

\section{Research model and hypothesis}

Based on literature this study examines the relation between Information technology strategy and decision making figure (5) is the proposed model for this study, it is proposed that there is a positive impact of Information technology strategy on decision making, hence the following hypothesis has been proposed depending on table (7):

\section{H1: Information Technology Strategy affects Decision Making}

The results refer to the positive effect of Information Technology Strategy on decision making, there are high correlation between the variables $(0.675)$ with $\left(\mathrm{R}^{2}=\right.$ $0.455)$ and it is significant that $(\mathrm{P})$ refer to accept value (less than (0.05), and the regression equation is :

$$
\mathrm{Y}=\mathrm{a}+\mathrm{b} \mathrm{X}
$$

Decision Making $=0.672+0.867$ Information Technology Strategy
The statistical decision : this results support the H1 hypothesis

\section{H11: Srategic Planning affects Decision Making}

The results refer to the positive effect of strategic planning on decision making, there are high correlation between the variables $(0.730)$ with $\left(\mathrm{R}^{2}=0.532\right)$ and it is significant that $(\mathrm{P})$ refer to accept value (less than (0.05), and the regression equation is :

$\mathrm{Y}=\mathrm{a}+\mathrm{b} \mathrm{X}$

Decision Making $=1.634+0.588$ Srategic Planning

The statistical decision : this results support the H1 hypothesis

\section{H12: Knowledge Workers affects Decision Making}

The results refer to the positive effect of Knowledge Workers on decision making, there are high correlation between the variables $(0.693)$ with $\left(R^{2}=0.481\right)$ and it is 
significant that $(\mathrm{P})$ refer to accept value (less than (0.05), and the regression equation is :

$\mathrm{Y}=\mathrm{a}+\mathrm{b} \mathrm{X}$

\section{Decision Making $=1.427+0.597$ Knowledge Workers}

The statistical decision : this results support the $\mathrm{H} 2$ hypothesis

\section{H13: Information System affects Decision Making}

The results refer to the positive effect of Information System on decision making, there are high correlation between the variables $(0.736)$ with $\left(\mathrm{R}^{2}=0.542\right)$ and it is significant that $(\mathrm{P})$ refer to accept value (less than $(0.05)$, and the regression equation is :

$\mathrm{Y}=\mathrm{a}+\mathrm{b} \mathrm{X}$

Decision Making $=1.149+0.675$ Information System

The statistical decision : this results support the $\mathrm{H} 3$ hypothesis

And with multiple regression the table (8) and figure (6) show the affect of the dimension together, it seems there are positive affect for the dimensions (Strategic Planning, Knowledge Workers, Information System) on decision making, the correlation between the variables $(0.814)$ with $\left(\mathrm{R}^{2}=0.663\right)$ and it is significant that $(\mathrm{P})$ refer to accept value (less than (0.05), and the regression equation is :

$\mathrm{Y}=\mathrm{a}+\mathrm{b} 1 \mathrm{X} 1+\mathrm{b} 2 \mathrm{X} 2+\mathrm{b} 3 \mathrm{X} 3$

Decision Making $=0.740+0.263 \mathrm{X} 1+0.227 \mathrm{X} 2+0.301$ X3

when :

$X 1$ : Strategic Planning

$X 1$ : Knowledge Workers

$X 1$ : Information System

This research investigated the impact of information technology strategy (Strategic Planning, Knowledge Workers, Information System) on decision making in Baghdad hospital, all of the respondents understand clearly what information technology strategy means and they practice it with limitation due to restricted financial resources, the percentage of knowledge workers is high in this hospital, it may be because this is teaching hospital, so it include high level of workers. In order to achieve the objectives of this research and test the hypothesis a questionnaire was administrated to 156 doctors, structural modeling equation using to illustrate the model, regression equation was used to test the relation between variables.

The research findings indicated that all dimensions of this research has a positive impact on decision making, and Information System has a highest impact among these dimensions, that means doctors in hospitals need information technology strategy to make their decisions, and this improve their ability to do so,

Despite of the limitations of the current research, some future research directions are suggested. First research should focus on the new technology in healthcare, second researcher can also examine the relation between knowledge sharing between doctors in hospital and decision making.

\section{References}

Akdeniz, C. Key Questions in Strategic Planning, Createspace Independent Pub,2015.

Altameem Arwa A., Aldrees,Abeer I. and Nuha A. Alsaeed, Strategic Information Systems Planning (SISP), World Congress on Engineering and Computer Science Vol I, 2014.

Aref, Maha,the relation between information system and marketing, international journal of green studies,issue24,2012.

Balatesh, iden, strategic decision making,Nel co.,2015.

Bildstein, Ingo and Gueldenberg Stefan, "Effective leadership of knowledge workers: results of an intercultural business study" Emerald Group Publishing Limited, Research Review, Vol. 25 No. 0,2013 .

Chiesa V., R\&D Strategy and Organization, Imperial College Press, 2001.

Chi-Hung Yeh, Gwo-Guang Lee, Jung-Chi Pai, "How information system capability affects e-business information technology strategy implementation: An empirical study in Taiwan", Business Process Management Journal, Vol. 18 Issue: 2, pp.197218,2012 .

Cleophus G., et al., information systems as a strategic partner in organizational performance, Journal of Management and Marketing Research,vol10,2012.

Davenport, Thomas H, "Thinking For a Living," Library of Congress Cataloging,2005. 
Denisi, Angelo S, \& Griffin, Ricky W, "Human Resource Management", Houghton Mifflin Company, Boston, USA, 2001.

George M., O'Brien A.,Introduction to information system, 16th edition,McGraw Hill,Irwin,2013.

Gilligan, Colin; Wilson, Richard, M. S.,(Strategic Marketing Planning), Butterworth Heinemann,2003.

Hamel G., Parahald, The Core Competence of Corporation, HarvardBusiness Review, 1990.

Hanschke, Inge, Strategic IT Management, A Toolkit for Enterprise, Architecture Management, SpringerVerlag Berlin Heidelberg,2010.

Kemerer C., Sosa G.,System development risks in strategic information systems,journal ofinformation and software technology, vol33,1991.

Khalil, T.,Management of Technology: the Key to Competitiveness and Wealth Creation. Singapore: McGraw-Hill, 2000.

Kriemadis \& Theakou, Thanos\& Elena," Strategic Planning Models in Public and Non-Profit Sport Organizations"Department of Sport Management, University of Peloponnese SMIJ-VOL.3, Number 2,2007.

Liu, Liang \& Chai, Huaqi"Based on The Balanced Score Card: Performance Evaluation of knowledge workers", IEEE, 2011.

McKeen, James D \& Smith, Heathcr A, Information technology strategy In action, 1st ed, Pearson Education, Inc., Upper Saddle River, New Jersey,2009.

McKeen, James D \& Smith, Heathcr A, IT strategy In action, 1st ed, Pearson Education, Inc., Upper Saddle River, New Jersey,2009.

McNamara,Carter, " Field Guide to Nonprofit strategic planning and Facilitation" Third Edition,
Authenticity Consulting, LLC Minneapolis, MN USA,2008. http:// WWW.Managementthelp

Moori D., lauden L., the impact of information system in decision making, internationa journal of green studies, issue 24,2012.

Nadler Moodi, Marlin, Strategic Planning : Part 1 APNAS Inclusionary Process, Journal of the American Psychiatric Nurses Association, 18 (2) pp. $127-128,2012$.

Noe,RaymondA\&Hollenbeck,JohnR\&Gerhart,Barry\&W right,Patrick.M, "Human Resource Management",5th,McGraw-Hill Irwin,2006.

Reix,Robert, systèmed'information et management des organisations, Vuibert, 3ème édition, paris, 2000,

Rothaermel,Frank, Strategic Management concepts \& cases, Published by McGrawHill/Irwin Companics, Americas,New York,2013.

Schilling, M.A. and Hill, W.L. Managing the New Product Development Process: Strategic Imperatives, Academy of Management Executive, Vol. 12, No. 3, August, 1998.

Shalan,H., Management reform through technology, third international conference of reform, naworoz university, 2017.

Shimary, Sadiqrashid, Azzawi, basil mohammed, Impact of strategic factors on decision making, Baghdad College of Economic Science,issue 34,2013

Siez M., information, knowledge, decisions, noor publisher,2011.

Wilson Frank, How to build pragmatic comprehensive information technology strategy,2013.

Zoltán G., Lajos S.,Middle Managers' Maturity of Knowledge Sharing: Investigation of Middle Managers Working at Medium- and Large-sized Enterprises, Electronic Journal of Knowledge Management Volume 10 Issue 12012.

\section{How to cite this article:}

Safaa Tayyeh Mohammed. 2017. Impact of Information Technology Strategy on Decision Making in Healthcare Sector: An empirical study in Baghdad Teaching hospital. Int.J.Curr.Res.Aca.Rev. 5(8), 100-111.

doi: https://doi.org/10.20546/ijcrar.2017.508.015 